\title{
WHAT IS JEWISH \\ IN JEWISH PHILOSOPHY?
}

\author{
KARL-JoHAN ILLMAN \\ Abo

In trying to answer the question "What is Jewish in Jewish Philosophy" I have to address at least two other questions. First "What do we mean by Jewish Philosophy?" And second: "What can be considered Jewish in this?" I shall address the questions in this order.

\section{What do We mean by 'JeWIsh Philosophy'?}

I cannot here go into the historical question about what those who used the category 'Jewish Philosophy' may have meant by this. Rather I will try to sort out the possible meanings of the expression and then I shall explain my own standpoint.

It is of course obvious that we cannot ignore the fact that 'Jewish philosophy' is a composite of 'Jewish' and 'philosophy'. To be sure, both of these terms can be understood in different ways. I presume that 'Jewish' must in this case be connected with 'Jewish tradition' or 'Jewish religion' or both. There is a third alternative, however, namely that 'Jewish' should primarily be connected with 'Jew'. In deciding which connection should be regarded as primary, I think that when speaking of 'Jewish' in connection with 'philosophy' we should not primarily think about the individuals who engage in 'philosophy'. Rather we should think about the tradition which makes up the subject matter or which guides the approach to philosophical questions. If we fail to do this, 'Jewish philosophy' would be what any Jewish person does when he or she engages in philosophy. And that would be a troublesome definition, to say the least, because it would only depend on our definition of "who is a Jew?" And, as we know, this question would take us into endless discussions about how to answer it in a proper way: for instance in a religious or in an ethnic way? 
The word 'Jewish' in connection with 'philosophy', therefore, primarily refers to the subject matter of and attitude to philosophy. Secondarily, I think that it has to do also with the individuals who engage in this activity.

The word 'philosophy' also needs some clarification. By 'philosophy' I do not mean 'thought' in general, but rather what has historically come to constitute the discipline of philosophy in the tradition of the ancient Greeks. Within this tradition I recommend we take the discipline in its broader sense, which also includes it being used to mean thinking about God, his relation to Man, and religion. It should, accordingly, not be restricted to modern trends and definitions of what may properly be called philosophy. I would not draw a clear border line between 'philosophy' and 'theology'. The reason for this is that, in Antiquity as well as in Medieval times, those two fields have very much overlapped, and they still continue to do so. We should not, I think, try to exclude what, during the classical periods of Judaism and Christianity, has been regarded as 'philosophy' because this category included almost everything which was regarded as important for Jews and Christians in those times.

Some of the scholars who have recently tried to define 'Jewish philosophy' seem to require of it that (I) the way of thinking should be philosophical, which means that is it has to be informed according to classical philosophical tradition, and (2) Jewish philosophy has to reflect on Jewish texts or Jewish traditions. What they usually do not comment upon is whether those engaged in Jewish philosophy personally should be Jewish, regard themselves to be Jewish or be regarded by others as Jewish. This last topic has an embarrassing ethnical or religious ring to it, which may be the reason why it is avoided. I prefer to approach the question from the opposite angle asking: would you consider a person who is not Jewish to be a 'Jewish philosopher' or would you say that a non-Jewish person can produce 'Jewish philosophy'? I expect you to answer no! A non-Jewish person can write about Jewish philosophy but he would not himself produce Jewish philosophy.

It seems to me therefore, that the Jewish identity of the person who is regarded as being engaged in Jewish philosophy, is in fact usually considered to be self-evident. But it should be spelled out: Jewish philosophy is produced only by people who themselves are Jewish.

Another important question when discussing 'Jewish Philosophy' is whether, by this term, we mean a discipline within general philosophy or not. This question was taken up by Daniel H. Frank in his introduction to the work History of Jewish Philosophy edited by himself and Oliver Leaman. ${ }^{2}$ Before I come to his answer, I shall review his argument to a certain extent.

Frank points out that the question "What is Jewish Philosophy?" is not a 
perennial one, although some may think this is the case. Many seem to think that there is something, an 'essence of Jewish philosophy', which sets it apart from all other philosophy. I quote:

The discussion of the issue demands that one should isolate common strands in the thought of Philo, Saadia, Maimonides, Crescas, (maybe) Spinoza, Mendelsohn, Cohen, Buber, Rosenzweig, Levinas, and others. This may or may not be possible to do, but it is important to realize at once that reflection on the nature of Jewish philosophy is of comparatively recent vintage. We are fooled into thinking that the question, what is Jewish philosophy? is a perennial one, because its subject matter, Jewish philosophy, extends far into the past in a unified and connected way. But so characterized, the subject matter is question-begging, for the supposition that all the thinkers we have listed are Jewish philosophers, in some non-trivial sense, and that they are together engaged in something called "Jewish philosophy" is a construct we impose upon the past by virtue of the very question we are asking....

'Jewish philosophy' is an academic discipline. It is an invention... of nineteenth-century historians, intent on bringing together certain thinkers, while simultaneously excluding others. Before the invention of Jewish philosophy as an academic discipline no one asked or wondered about the nature of Jewish philosophy, quite because the subject did not exist. [Frank 1997, 2]

Frank concludes by saying that once a discipline has been created we seem to think that there is 'out there' an issue, Jewish philosophy, which awaits study and analysis. But in fact the creation of a discipline is to a large extent also a creation of the subject to be studied.

We may consider for instance whether a figure like Spinoza would fit into a subject like Jewish philosophy. To be sure, he was a Jew, and he reflected on Judaism, the Bible and so on. But if we could have asked him what he considered himself to be, he would probably have answered "a philosopher". This is not, of course, because he was or was regarded a heretic, but simply because he thought he was concerned with philosophy and not with Jewish philosophy. In fact this does not change much if we turn to a normative Jewish philosopher like Maimonides. He did not philosophize in a certain Jewish way. He asked and answered philosophical questions, about existence, truth, knowledge and so on. He used Aristotelian categories when speculating about his Jewish tradition. The same holds true for Moses Mendelssohn and other later Jewish thinkers. These authors did not think of themselves as being engaged in something called 'Jewish philosophy', because the category did not exist, much less the discipline. Frank's definition runs in this way (Frank 1997, 6): 
Jewish philosophy is an academic discipline invented in the nineteenth century by scholars intent on gaining a foothold of academic respectability.

Once the category 'Jewish Philosophy' was created by the German Wissenschaft des Judentums it was associated with 'general philosophy' in order to include certain thinkers and themes and exclude others. Frank observes that this category came to exclude Jewish mysticism in a way foreign to the classical medieval Jewish philosophers.

Frank does not, of course, deny that the philosophers connected with the category 'Jewish philosophy' regarded themselves as Jews. Neither does he deny that they addressed Jewish tradition. What he denies is only the assumption that there is 'out there' a subject which starts in antiquity and continues until today which we can properly call 'Jewish philosophy'. Such an entity is a modern construction. There is no such continuity between Jewish philosophers and their thoughts that we could rightfully speak of a category called Jewish philosophy. And there is no such awareness among the philosophers of earlier centuries that what they were doing was occupying themselves with Jewish philosophy.

I can agree with Frank on these particular points. But I would like to emphasize more that there still remains the phenomenon, or even tradition, of Jews thinking about Judaism, or Jewish themes. And therefore I proceed to the second and main question of my article.

\section{WHAT IS JEWISH IN THIS PHENOMENON OR TRADITION?}

If we cannot rightfully speak of 'Jewish philosophy' as a discipline of philosophy in general, we can still speak of 'Jewish philosophers', 'Jewish theologians', and 'Jewish writers'. These categories do not suppose that there is in thinking about certain questions a specific 'Jewish way'. What we can maintain about such people is (I) that they were Jews and regarded themselves as such, and (2) that they thought and wrote about Judaism.

I consider these two points essential in trying to answer the second question. As I already said, a Jewish philosopher has self-evidently to be a Jew. This is not trivial; because even if you agree in principle, you may come to think about the notorious question "Who is a Jew?". This could easily result in your dismissing the whole question. I therefore remind you of the situation in Europe in the igth century. Many prominent philosophers had a Jewish background, but some of them were themselves no longer Jews, while others were and remained Jews. I give you some examples:

Edmund Husserl (1859-1938), was the initiator of the phenomenological branch of philosophy. His parents were Jews but both had converted to protestant Christianity. 
Max Scheler (1874-1928), one of Husserl's important students, had a Jewish mother, but he converted himself to Catholicism when he married a Catholic woman. After his divorce he left the Catholic church but did not turn back to Judaism.

Georg Simmel (1858-1918), professor of philosophy in Berlin. His parents, like Husserl's, had converted to Christianity.

Henri Bergson (1859-194I) was strongly attracted to Catholicism, but he never formally left Judaism.

Of these four philosophers, Husserl, Scheler and Simmel each have had a considerable influence on Jewish thinkers such as Martin Buber, Franz Rosenzweig and Emmanuel Lévinas. They seem to have had a stronger impact than the only Jew among them, Bergson. Is it not an irony that those who most influenced Jewish thinkers were themselves no longer Jews? This seems to imply that there was and is among philosophers no clear boarder line between those who were Jews and those who were not Jews.

But this is not the whole truth of the matter. Take for example: Hermann Cohen (1842-1918) who was and remained a Jew and had perhaps the strongest influence on Buber, Rosenzweig and Lévinas; and Rosenzweig, who was engaged in an intensive debate which ended in disagreement with his friends Hans Ehrenberg and Eugen Rosenstock. Both had converted to Christianity, Ehrenberg to Protestantism, Rosenstock to Catholicism. What did they discuss? They discussed the question whether Christianity was the true religion or not, and whether this meant that Judaism had played its role to the end and was about to disappear. Rosenzweig had already promised his friends to follow the conclusions of this seemingly inevitable fact and to convert, but he still wanted to study Judaism thoroughly in order to make his conversion "as a Jew and not as a heathen". His study, however, made him regret his promise to convert and he remained a Jew and he embarked on the road back to Judaism. When Rosenzweig decided to remain a Jew, he at the same time remained 'a Jewish philosopher'. His friends who had converted to Christianity, on the other hand, became Christian philosophers. They did so not only in a formal way, but in their whole outlook and their orientation toward their new tradition.

\section{$\infty$}

In deciding whom I would call a Jewish philosopher and whom I would not, I have to rely on another important criterion, as well. I expect a Jewish thinker to reflect on his or her Jewish tradition when philosophizing. Thus my definition runs in the following way: a Jewish philosopher is a person who is Jewish and philosophises about Judaism.

To be sure, the problems of any Jewish philosopher who reflects on his/her own tradition today are different from what they were during medieval times 
when loyalty toward Jewish tradition was self-evident. He was then supposed to explain his tradition, not question it. Reason and Revelation were compatible. A Jewish philosopher of today may have a divided loyalty, toward his/her tradition and toward his/her discipline, philosophy. His or her thought should, in some reasonable way, be philosophical, and it should in one way or another comment on Judaism, or Jewish tradition.

In conclusion, when answering the question "What is Jewish in Jewish Philosophy?" I repeat: Jewish in Jewish philosophy is in some reasonable way, (I) the identity of the philosopher and (2) the theme or the subject of his or her philosophy. We can speak of 'Jewish philosophy' without thinking about it as a subdivision of general philosophy. It is then what Jewish philosophers do when they make Jewish tradition or Jewish questions their subject matter.

\section{Notes}

r. Thus Emil L. Fackenheim, What Is Jewish Philosophy? Emil L. Fackenheim, Jewish philosophers and Jewish Philosophy, ed. by Michael L. Morgan. Indiana UP: Bloomington and Indianapolis 1996,165-184, Jewish Philosophy in the Academia, ibid., 185-192. Cf. Oliver Leaman, Evil and Suffering in Jewish Philosophy. Cambridge UP, 6-10.

2. What is Jewish Philosophy? Daniel H. Frank and Oliver Leaman (eds.) History of Jewish Philosophy. Routledge History of World Philosophies. Vol 2. London and New York: Routledge 1997, I-IO.

\section{SAMMANFATTNING}

Daniel H. Frank har rätt när han framhåller att "judisk filosofi" inte betecknar en underavdelning inom den allmänna filosofin utan en akademisk disciplin som skapades i början av I8oo-talet av rörelsen Wissenschaft des Judentums som ville legitimera det vetenskapliga studiet av judendomen, däribland också filosoferandet över judendomen. I äldre tid betraktade sig judiska filosofer som "filosofer" rätt och slätt. Men detta historiska sakförhållande betyder inte att vi bör avstå från termen "judisk filosofi". Vi bör i stället ge den en rimlig definition. För egen del anser jag att användningen av termen "judisk filosofi" bör uppfylla två kriterier:

I) det är en verksamhet som bedrivs av judar, och

2) det är en filosofisk verksamhet som har judendomen som sitt föremål.

Om punkt I kan man tillägga att ickejudar mycket väl kan filosofera över judendomen, men få skulle på allvar kalla detta "judisk filosofi”. Om punkt 2 kan man säga att det ter sig orimligt att kalla en verksamhet "judisk filosofi" som inte har något med judendomen att göra. Vardera kriteriet är ett slags elementär common sense-definition.

Mitt svar på rubrikens fråga "Vad är judiskt i judisk filosofi?" lyder följaktligen: filosofens identitet och ämnet eller temat för hans/hennes filosofiska tänkande. 